\title{
A Case of Churg-Strauss Syndrome Treated with Montelukast
}

\author{
Ceyda Anar $^{\mathrm{a}}$ İpek Ünsal $^{\mathrm{a}}$ Murat Erdal Ozanturk $^{\mathrm{a}}$ Hüseyin Halilçolar ${ }^{\mathrm{a}}$ \\ Nur Yucel ${ }^{b}$ \\ ${ }^{a}$ Division of Pulmonary Medicine and ${ }^{b}$ Division of Pathology, Dr. Suat Seren Chest Disease and Surgery Training \\ and Research Hospital, Izmir, Turkey
}

\section{Key Words}

Asthma $\cdot$ Montelukast $\cdot$ Allergic rhinitis $\cdot$ Churg-Strauss syndrome

\begin{abstract}
Objective: To report a case of Churg-Strauss syndrome who had asthma and allergic rhinitis treated with montelukast. Clinical Presentation and Intervention: A nonsmoking 59-year-old woman presented with fever, hemoptysis and dyspnea. Past medical history included allergic rhinitis and asthma which were diagnosed 18 years ago. The asthma was treated successfully with inhaled salmeterol and beclamethasone. She also received montelukast ( $10 \mathrm{mg} /$ day) for 3 years. Although her chest X-ray was normal a week earlier, she had widespread bilateral pulmonary infiltrates on admission. She had leukocytosis $\left(12.5 \times 10^{9} / \mathrm{l}\right)$ with eosinophilia (15.6\%). Her total IgE count was $550 \mathrm{U} / \mathrm{ml}$. Testing for protoplasmicstaining antineutrophil cytoplasmic antibodies was positive. Bronchoalveolar lavage could not be performed due to bronchospasm and severe hypoxemia; however, mucosal biopsies were obtained, which revealed eosinophil leukocytes in the lumen and walls of small vessels. She was diagnosed to have Churg-Strauss syndrome and had remarkable clinical improvement on day 5 with high-dose of oral prednisolone
\end{abstract}

( $50 \mathrm{mg} /$ day). Radiological improvement was detected at the end of the second week. Conclusion: This case shows the importance of being aware that leukotriene receptor antagonists could cause Churg-Strauss syndrome, in spite of the uncertainty about its mechanism.

Copyright $\odot 2011$ S. Karger AG, Basel

\section{Introduction}

Churg-Strauss syndrome (CSS) is a rare systemic vasculitis of unknown etiology characterized by necrotizing small-vessel vasculitis and eosinophil-rich granulomatous inflammation of tissues and vessels, associated with asthma and eosinophilia [1]. The incidence of this syndrome is $2.4 / \mathrm{million} /$ year in the general population, and $6-18 /$ million/year in patients with asthma [2]. Recently, it has been increasingly recognized in asthmatic patients treated with leukotriene receptor antagonists (LTRAs), which was approved for the prophylaxis and treatment of asthma and allergic rhinitis. The incidence in such cases is determined as $60 /$ million/year. The exact nature of this association is not fully understood; however, a possible link between cysteinyl LTRAs and CSS has been suggested by a series of published case reports $[2,3]$. Some inves-

\section{KARGER \\ Fax +4161306 1234 \\ E-Mail karger@karger.ch}

www.karger.com
(ㄷ) 2011 S. Karger AG, Basel

$1011-7571 / 12 / 0212-0186 \$ 38.00 / 0$

Accessible online at:

www.karger.com $/ \mathrm{mpp}$
Ceyda Anar

Department of Chest Diseases

Dr. Suat Seren Chest Disease and Surgery Training and Research Hospital

İzmir (Turkey)

Tel. +90 505484 0070, E-Mail drceydaanar@hotmail.com 

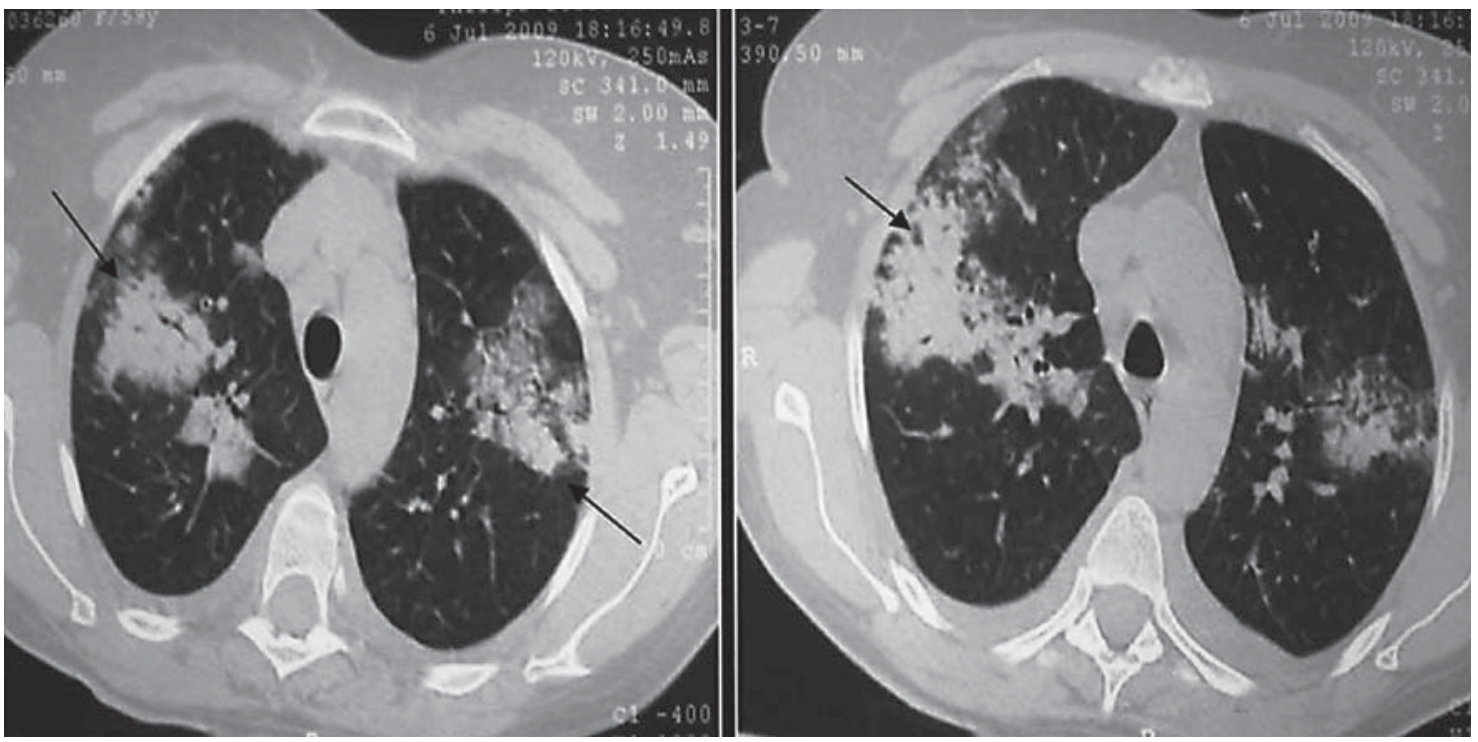

Fig. 1. Small patchy widespread airspace opacities, and consolidations with air-bronchograms.

tigators attributed this association to oral steroid withdrawal, because of the efficacy of LTRAs in improving airway obstruction in patients with severe asthma $[4,5]$. We report a case of CSS who had asthma and allergic rhinitis treated with montelukast.

\section{Case Report}

A nonsmoking 59-year-old female presented to hospital with fever, hemoptysis and dyspnea of 7 days. A presumptive diagnosis of pneumonia was made prior to admission, and levofloxacin was commenced. Despite treatment for 1 week, her symptoms worsened.

Past medical history included allergic rhinitis and asthma diagnosed 18 years ago. The asthma had been treated successfully with inhaled salmeterol and beclamethasone for 3 years. Following progressive worsening of nasal obstruction, polypectomy was performed twice, 6 and 3 years prior to admission. She was on montelukast (10 mg/day) for 3 years. Although her chest X-ray was normal a week earlier, she had widespread bilateral infiltrates on admission. High-resolution computerized tomography demonstrated small patchy widespread airspace opacities, and consolidations with air bronchograms (fig. 1). She had leukocytosis (12.5 $\times 10^{9} / \mathrm{l}$ ) with eosinophilia (15.6\%). Erythrocyte sedimentation rate was elevated $(74 \mathrm{~mm} / \mathrm{h})$. She was hypoxemic with a $\mathrm{PO}_{2}$ of $43 \mathrm{~mm} \mathrm{Hg}$. Pleural fluid analysis revealed eosinophilic predominance. Total IgE count was $550 \mathrm{IU} / \mathrm{ml}$. Testing for perinuclear staining antineutrophil cytoplasmic antibodies was positive. Paranasal sinus computerized tomography showed diffuse mucosal thickening, leading to complete obstruction of both ethmoidal and maxillar sinuses. Bronchoalveolar lavage could not be per-

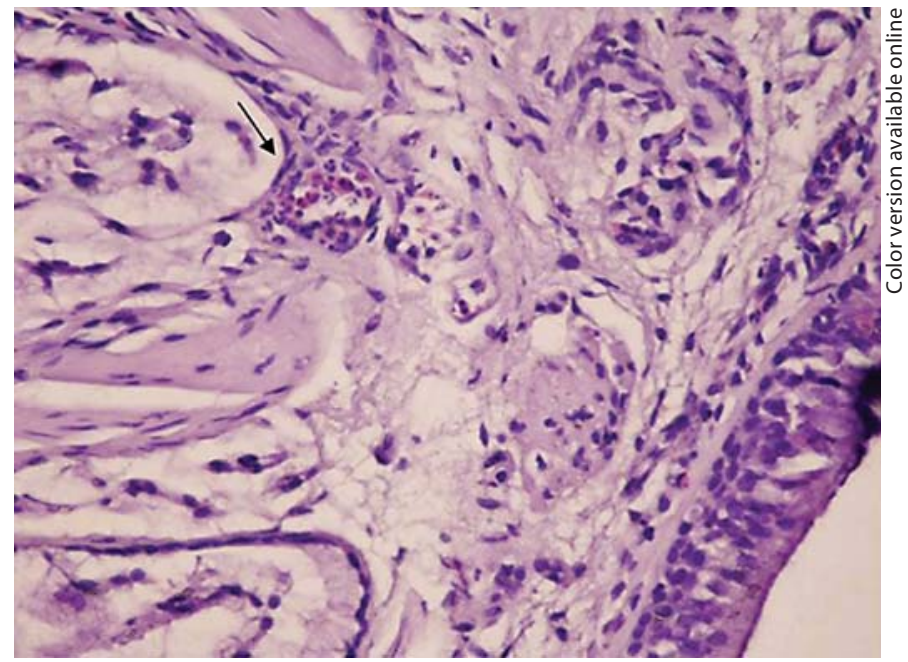

Fig. 2. Eosinophil leukocytes in lumens and walls of small vessels.

formed due to bronchospasm and severe hypoxemia; however, mucosal biopsies were obtained, which revealed eosinophil leukocytes in lumens and walls of small vessels (fig. 2). An echocardiogram showed moderate pulmonary hypertension. EMG was performed due to initial paresthesia of upper extremities, which was normal.

The patient was diagnosed as having CSS according the American College of Rheumatology diagnostic criteria, four of six being present. 


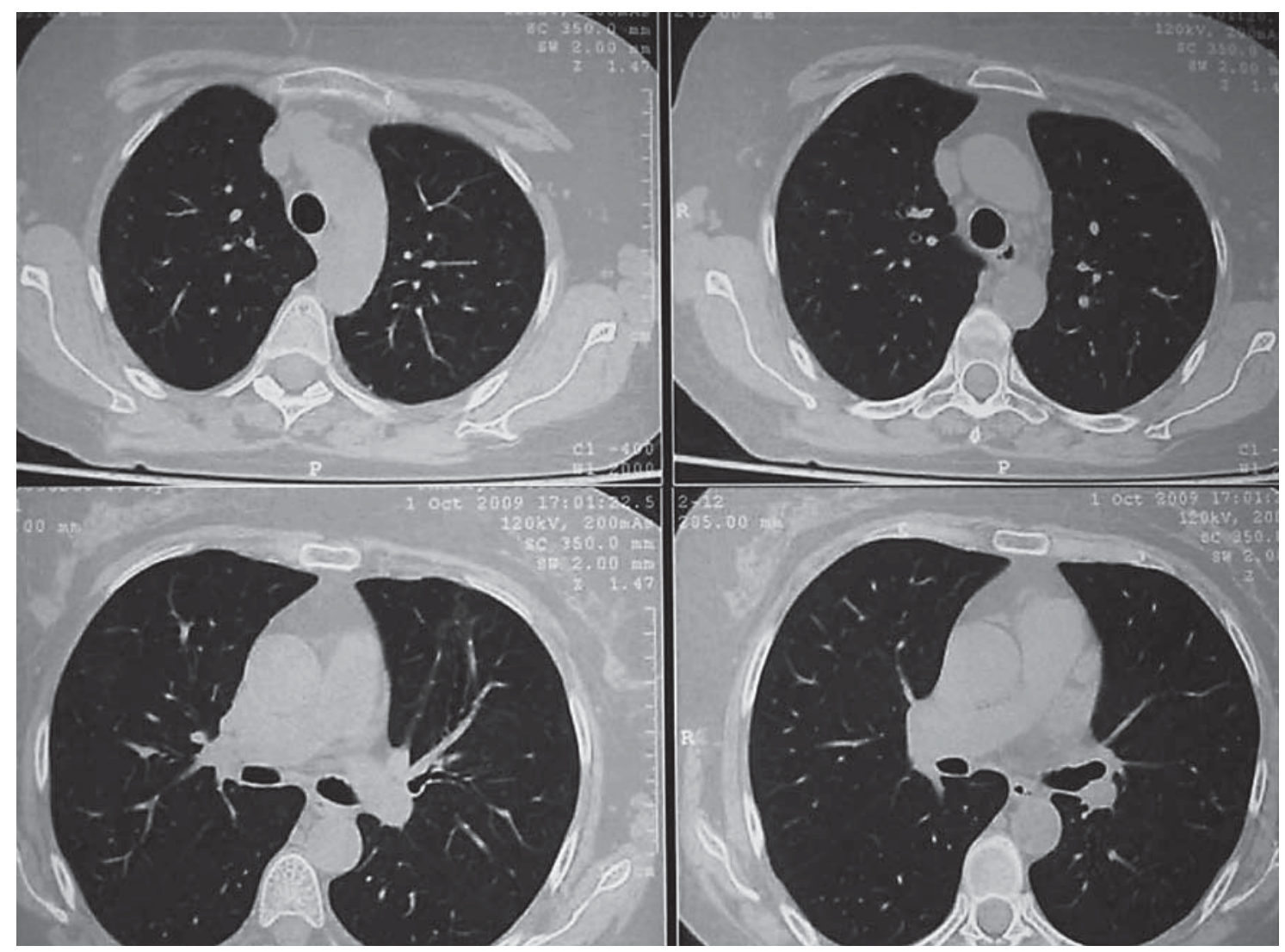

Fig. 3. Bilateral infiltrates were regressed completely at the end of second month.

She had remarkable clinical improvement on day 5 with highdose oral prednisolone (50 mg/day); her eosinophilia count (6.4\%) decreased at the end of the first week and radiological improvement was detected at the end of the second week. Erythrocyte sedimentation rate was $40 \mathrm{~mm} / \mathrm{h}$ at the end of 1 month. There was complete resolution at the end of the second month (fig. 3).

\section{Discussion}

CSS is characterized by the triad of asthma, hypereosinophilia, and necrotizing vasculitis, which was first described in 1951. The etiology is unknown. The diagnosis is made according to at least four of the following six features: (a) moderate to severe asthma; (b) peripheral blood eosinophilia (>10\%); (c) mononeuropathy or polyneuropathy; (d) pulmonary infiltrates; (e) paranasal sinus abnormality, and (f) extravascular eosinophils [6]. The typical patient with CSS is a middle-aged individual (ages $38-50)$ with a history of asthma. The distribution of the disease among males and females is approximately equal.
Patients with CSS often undergo three distinct phases: atopy/sinusitis/asthma, eosinophilia, and vasculitis. The first phase includes asthma symptoms which may begin long before the onset of vasculitis. Vaglio et al. [7] stopped prednisone therapy 9 months later but they resumed soon after withdrawal because of relapsing asthma. So, asthma often improves before the onset of the vasculitic symptoms of CSS, as in our patient [7]. Other early findings include nasal polyps and allergic rhinitis. Our patient with a long history of allergic rhinitis and asthma requiring nasal polyp resection is a typical example of the first phase. The second phase of the disease is often marked by eosinophilia. The percentage of eosinophils in peripheral blood and tissues may be as high as $60 \%$. Our patient also had peripheral eosinophilia as well as eosinophil-dominant pleurisy indicating the second phase. The third phase of the illness is characterized by vasculitis, which involves mostly the lungs, skin, nerves, kidneys, and other organs. 
An association between LTRAs and CSS has been reported following increased use of LTRAs in the management of moderate to severe asthma [8]. Most patients are found to have CSS 3 days to 9 months following initiation of the LTRAs [9]. Montelukast is reported to cause a 4.5fold higher risk within the first 3 months of the treatment [10]. Our patient was treated for 3 years, which is longer than previous cases treated with montelukast.

There are several hypotheses about antileukotrieneinduced CSS. The coincidence of CSS along with the use of LTRAs is one of them. Another hypothesis suggests that the success of LTRAs in controlling the asthma symptoms leads to cessation of steroid use, which in fact unmasks the previously controlled CSS symptoms. However, it cannot explain the development of CSS in patients who do not have concurrent steroid use $[2,3,11]$. There are a few supportive reports with asthmatic patients on LTRAs who never used steroids [12], as in the case of our patient. Another hypothesis, the occurrence of a hypersensitivity reaction to LTRAs, is also unlikely, because the histopathological picture in a hypersensitivity reaction shows leukocytoclastic vasculitis rather than a granulomatous lesion [9]. Another assumption is the increase of circulating LTB4 with the blockade of cysteinil receptors leading to a vasculitic phase by chemoattraction of neutrophils and eosinophils. However, reports showing the blockade of LTB4 by a 5-lipooxygenase inhibitor, zileutoun, causing the same disease decrease the value of this hypothesis [11].

\section{Conclusion}

This case shows the importance of being aware that LTRAs could cause CSS, in spite of the uncertainty about its mechanism.

\section{References}

1 Rochester CL: The eosinophilic pneumonias; in Fishman AP: Fishman's Pulmonary Diseases and Disorders. New York, McGrawHill, 1998, pp 1133-1150.

$\checkmark 2$ Wechsler ME, Finn D, Gunawardena D, Westlake R, Barker A, Haranath SP, Pauwels RA, Kips JC, Drazen JM: Churg-Strauss syndrome in patients receiving montelukast as treatment for asthma. Chest 2000;117:708713.

-3 Tuggey JM, Hosker HSR: Churg-Strauss syndrome associated with montelukast therapy. Thorax 2000;55:805-806.

$\checkmark 4$ Girszyn N, Amiot N, Lahaxe L, Cuvelier A, Courville P, Marie I: Churg-Strauss syndrome associated with montelukast therapy. QJ Med 2008;101:669-671.
5 Kaliterna DM, Perković D, Radić M: ChurgStrauss syndrome associated with montelukast therapy. J Asthma 2009;46:604-605.

6 Masi AT, Hunder GG, Lie JT, Michel BA Bloch DA, Arend WP, Calabrese LH, Edworthy SM, Fauci AS, Leavitt RY, et al: The American College of Rheumatology 1990 criteria for the classification of ChurgStrauss syndrome (allergic granulomatosis and angiitis). Arthritis Rheum 1990;33: 1094-1100.

$\checkmark 7$ Vaglio A, Casazza I, Graselli C, Corradi D, Sinico R, Buzio C: Churge-Strauss syndrome. Kidney Int 2009;76:1006-1011.

$\checkmark 8$ Lynch KR, O’Neill GP, Liu Q, Im DS, Sawyer N, Metters KM, Coulombe N, Abramovitz M, Figueroa DJ, Zeng Z, et al: Characterisation of the human cysteinyl leukotriene CysLT1 receptor. Nature 1999;399:789-793. $\checkmark 9$ Guilpain P, Viallard JF, Lagarde P, Cohen P, Kambouchner M, Pellegrin JL, Guillevin L: Churg-Strauss syndrome in two patients receiving montelukast. Rheumatology 2002; 41:535-539.

10 Hauser T, Mahr A, Metzler C, Coste J, Sommerstein R, Gross WL, Guillevin L, Hellmich B: The leukotriene receptor antagonist montelukast and the risk of Churg-Strauss syndrome: a case-crossover study. Thorax 2008;63:847-849.

11 Josefson D: Asthma drug linked with ChurgStrauss syndrome. BMJ 1997;315:330.

12 Knoell DL, Lucas J, Allen JN: Churg Strauss syndrome associated with zafirlukast. Chest 1998; 114:332-334. 